\title{
KEPEMIMPINAN BERTUMBUH (STUDI KASUS KEPEMIMPINAN REKTOR UNNES)
}

\author{
Agung Kuswantoro, Ismiyati, Hana Netty Purasari
}

Fakultas Ekonomi

Universitas Negeri Semarang

A R T ICLE INFO

\section{Keywords: Growing Leadership, Universitas Negeri Semaramg}

Kata Kunci: Kepemimpinan

Bertumbuh, Universitas Negeri

Semarang

Corresponding author :

Agung Kuswantoro

agungbinmadik@mail.unnes.ac.id

\begin{abstract}
The purpose of this research is (1) to know the meaning of leadership grows (2) to know the character that is in the growing leadership (3) To know the theory used in the growing leadership. The type of research used in this study is qualitative research. The technique of determining the informant using purposive sampling (subject to purpose). The meaning of leadership grows refers to the tree philosophy. The tree (1) Cultivates leadership, (2) Strengthening the Leadership Tree, (3) arranging a network of leadership trees, (4) strong trees face storms, and (5) spray the new leadership shoots. The character in the growing leadership was to cultivate leadership seeds, which included understanding humanity and leadership. The theory used in the growing leadership is the theory of behaviour. The suggestion in this study was (1) the need for stronger theoretical support in the growth of leadership. (2) The institution or organization is suitable/appropriate to use this theory in the present time, because it is in accordance with the condition of society. Above, leadership grew based on the experience of a leader.
\end{abstract}

Abstrak: Tujuan penelitian ini adalah (1) untuk mengetahui makna kepemimpinan bertumbuh (2) untuk mengetahui karakter yang ada dalam kepemimpinan bertumbuh(3) untuk mengetahui teori yang digunakan dalam kepemimpinan bertumbuh. Jenis penelitian yang digunakan dalam penelitian ini adalah penelitian kualitatif. Teknik penentuan informan dengan menggunakan purposive sampling (subjek sesuai tujuan). Makna Kepemimpinan Bertumbuh mengacu pada filosofi pohon. Pohon itu (1) Menumbuhkan bibit kepemimpinan, (2) Memperkuat pohon kepemimpinan, (3) Merangkai jejaring pohon kepemimpinan, (4) Pohon kuat menghadapi badai, dan (5) Menyemai tunas kepempimpinan baru. Karakter dalam kepemimpinan bertumbuh yaitu menumbuhkan bibit kepemimpinan, yang meliputi memahami kemanusiaan dan kepemimpinan. Teori yang digunakan dalam kepemimpinan bertumbuh adalah teori perilaku. Saran dalam penelitian ini adalah (1) Perlunya dukungan teori yang lebih kuat dalam memaknai kepemimpinan bertumbuh. (2) Lembaga atau organisasi sangat cocok/tepat menggunakan teori ini di saat sekarang, karena sesuai dengan kondisi masyarakat. Terlebih, kepemimpinan bertumbuh berdasarkan kepada pengalaman seorang pemimpin. 


\section{Latar Belakang}

\section{PENDAHULUAN}

Kepemimpinan adalah bagian penting dari manajemen, tetapi bukan semuanya. Sebagian contoh para manajer harus merencanakan dan mengorganisasikan, tetapi peran utama pemimpin adalah mempengaruhi orang lain untuk mencapai tujuan yang ditetapkan dengan antusias. Ini bukti bahwa pemimpin boleh jadi manajer yang lemah apabila peranannya yang jelek menyebabkan kelompoknya bergerak kearah yang salah. Meskipun mereka dapat menyebabkan kelompoknya bergerak ke arah yang salah. Meskipun mereka dapat menggerakkan kelompok, mereka sama sekali tidak dapat menggerakkannya kearah pencapaian tujuan organisasi. Juga dimungkinkan adanya kombinasi lain. Seseorang boleh jadi pemimpin yang lemah, tetapi merupakan manajer yang relatif efektif, khususnya apabila ia kebetulan mengelola orang-orang yang sangat memahami pekerjaan mereka dan memiliki dorongan yang kuat untuk bekerja.

Semenjak Rektor Universitas Negeri Semarang (UNNES), Prof. Fathur Rokhman, M. Hum meluncurkan Buku Kepemimpinan Bertumbuh (2016) bahwa keberadaan konsep kepemimpinan bertumbuh menjadi sesuatu yang baru dalam kepemimpinan. Dalam acara bedah buku perdana, sejumlah tokoh pendidikan, politik, dan keagamaan hadir dalam acara itu. Rektor Universitas Diponegoro (Undip) Prof Dr Yos Johan Utama bersama Direktur Pembinaan Kelembagaan Kemristekdikti Dr Totok Prasetyo, dan Staf Ahli bidang Infrastruuktur Menristekdikti Ir Hari Purwanto MSc DIC menjadi pengulas. Selain itu, hadir pula anggota DPD Republik Indonesia Bambang Sadono, Gubernur Akpol, Gubernur Akmil, Pemimpin Pondok Pesantren Balekambang Jepara KH Makmun Abdullah juga hadir dalam acara yang disiarkan secara langung oleh Radio Idola itu (Tribun Jateng, edisi 9/12/2016).

Prof Fathur Rokhman, M. Hum menceritakan, buku itu merupakan catatan atas pengalamannya selama tiga tahun memimpin UNNES sebagai Rektor dan tujuh tahun menjadi Wakil Rektor bidang Pengembangan dan Kerjasama. Selain pengalaman praktis, sejumlah pandangan teoretis yang terbagi dalam lima bagian: menumbuhkan benih kepemimpinan, memperkuat kepemimpinan, meningkatkan efektivitas komunikasi, memimpin pada masa krisis, dan menyiapkan kepemimpinan generasi selanjutnya.

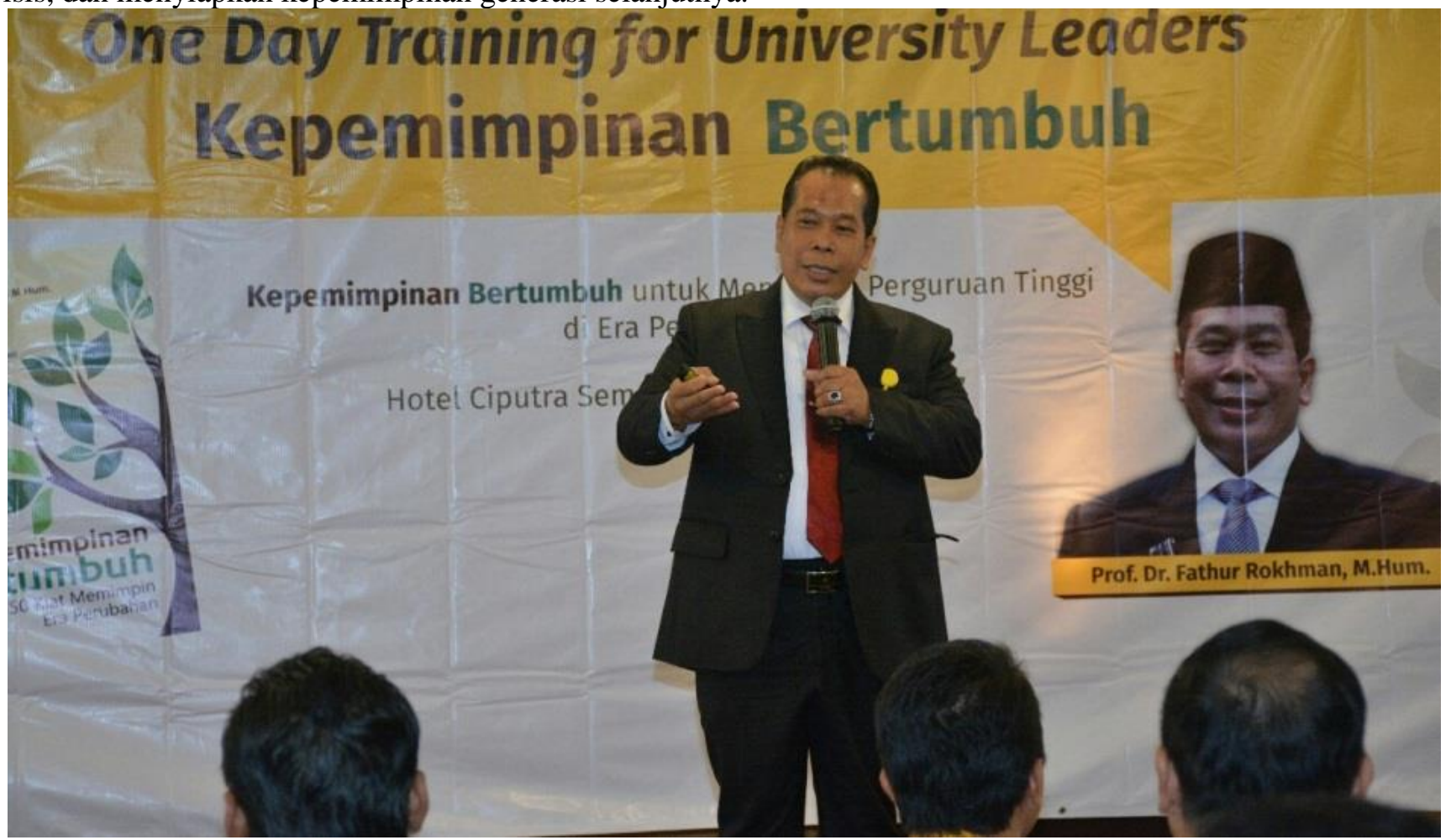

Gambar 1. One Day Trainning Kepemimpinan Bertumbuh di Semarang Sumber: http://Jateng.Tribunnews.Com/2016/12/08/Rektor-Unnes-Akan-Luncurkan-Buku-KepemimpinanBertumbuh 
Yuwono (2017) mengatakan Pelatihan Kepemimpinan Bertumbuh diadakan tidak hanya di UNNES, tetapi juga di luar UNNES seperti di Hotel Ciputra Semarang pada hari Kamis (16/11/2017). Pelatihan ini dihadiri oleh 48 peserta yang berasal dari berbagai universitas di seluruh Indonesia. Salah satu pesertanya, Rektor Universitas Muria Kudus, Dr. H. Suparnyo, SH.MS.. Ia mengatakan bahwa dimensi baru baginya untuk melihat kembali visi universitasnya melalui sudut pandang yang berbeda. Pendapat yang senada juga disampaikan oleh Dr. Bambang Kuncoro, M.Si., Wakil Rektor Bidang Kemahasiswaan Universitas Tidar dan Prof. Dr. Basri Modding dari Universitas Muslim Indonesia Makassar.

Pelatihan Kepemimpinan Bertumbuh juga dilakukan di Universitas Muria Kudus (UMK). Acara dihadiri oleh pimpinan lembaga, pimpinan fakultas dan pimpinan universitas di UMK. Prof. Fathur Rokhman hadir membawakan materi "Kepemimpinan Bertumbuh untuk Memimpin Perguruan Tinggi di Era Perubahan" (Selasa (13/2/2018 pada http://harakatuna, 2017).

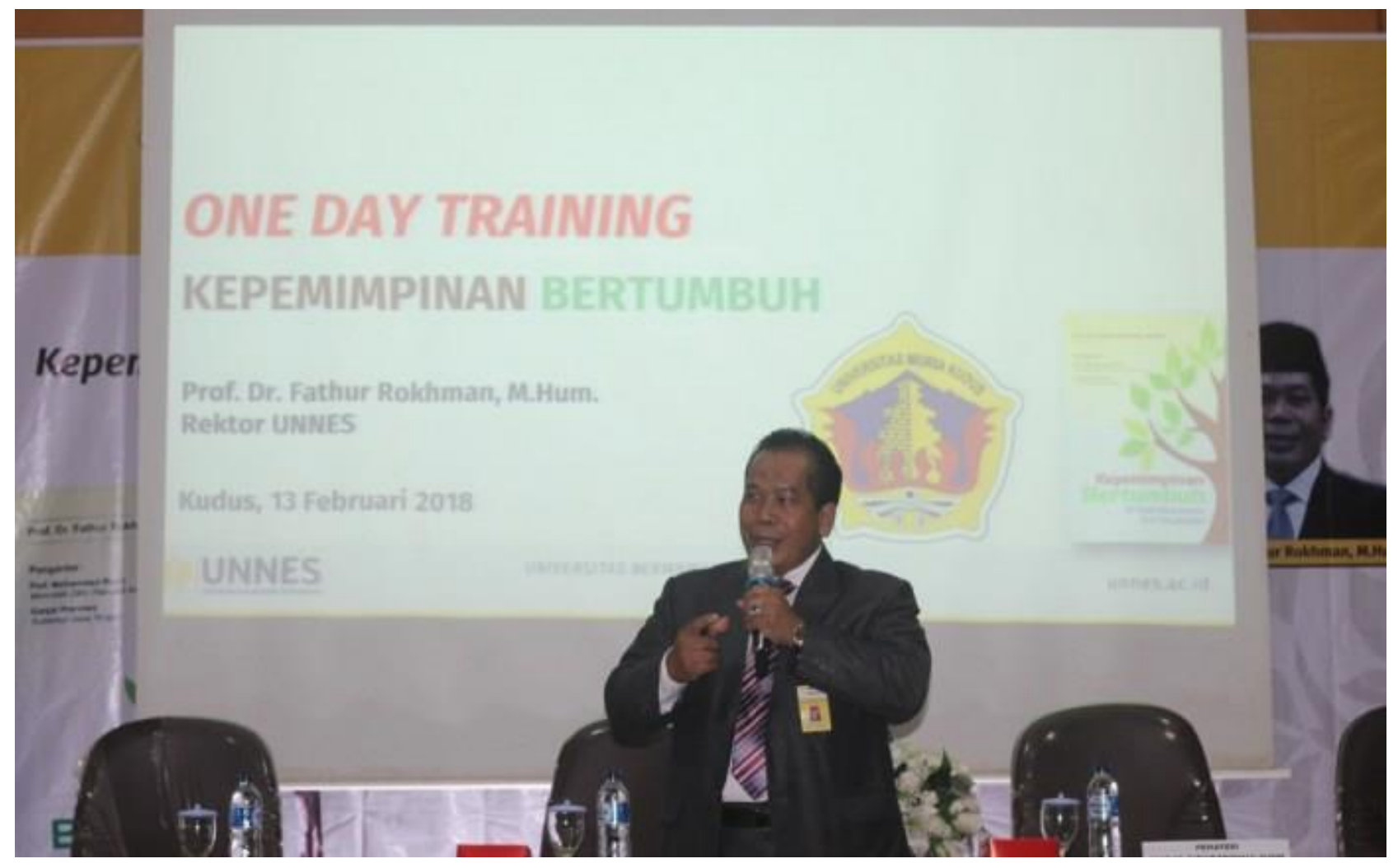

Gambar 2. One Day Trainning Kepemimpinan Bertumbuh di Kudus

Sumber : https://www.harakatuna.com/kepemimpinan-bertumbuh-ala-prof-fathur-rokhman.html

Dari penjelasan di atas, maka kami tertarik untuk meneliti Kepemimpinan Bertumbuh yang "digadang" oleh Prof. Fathur Rokhman, M.Hum selaku Rektor UNNES yang menerapkan model kepemimpinan tersebut. UNNES tercatat telah mengukir prestasi-prestasi baik di Dalam Negeri dan Luar Negeri. Kepemimpinan merupakan suatu proses yang di dalamnya terdapat interaksi yang dinamis antara pimpinan dan karyawan-karyawannya dalam suatu situasi atau lingkungan tertentu (Hughes, et al., 2012: 35). Dengan demikian dapat dikatakan bahwa kepemimpinan merupakan suatu konsep yang lebih luas dibandingkan dengan para pemimpin, dan studi kepemimpinan ini seharusnya melibatkan lebih dari pada sekedar mempelajari pemimpin sebagai individu, tetapi seharusnya juga melibatkan dua sisi yang lain, yaitu para karyawan dan situasi.

Pohon bisa menjadi analogi yang tepat untuk memahami kepemimpinan. Secara anatomi, pohon adalah organisme yang kompleks. Tidak hanya terdiri dari akar hingga daun, bunga dan buah, tetapi ada bagian-bagian 
mikro di dalam pohon. Masing-masing bagian bekerja agar pohon terus tumbuh menjadi bagian yang sangat penting dalam ekosistem yang kompleks.

Sifat paling mengagumkan dari tumbuhan adalah caranya tumbuh dalam suasana yang terus kondisi terus berubah. Pohon melakukan berbagai cara, bahkan kerap diluar dugaan manusia, untuk merespon perubahan di sekitarnya. Kemampuan adaptif pohon teruji sehingga terus bertahan hidup. Kepemimpinan juga seperti pohon: bertumbuh dan adaptif. Kedua sifat itu wajib dimiliki karena kepemimpinan senantiasa hadir dalam ruang sosial dan psikologis masyarakat terus berubah, nilai dan norma masyarakta juga terus berganti. Kepemimpinan yang baik, yakni kepemimpinan yang bertumbuh, merespon perubahan itu sebagai sarana meningkatkan efektivitasnya.

Setiap manusia adalah pemimpin. Ada benih kepemimpinan dalam setiap manusia. Benih itu akan berkecambah, tumbuh menjadi pohon, jika dipelihara dengan cara yang tepat. Kelak pohon itu bisa menadi sangat rindang yang menyejukkan, menghasilkan bunga yang wangi, dan kelak akan menghasilkan bunga yang wangi, dan kelak akan menghasilan buah dan benih yang baru sebagai awal generasi.

\section{TINJAUAN PUSTAKA}

Berkaitan dengan kepemimpinan budaya (2013) telah melakukan penelitian yang berkaitan dengan “Kearifan Lokal Budaya Jawa sebagai Basis Model Kepemimpinan Yang Efektif”. Dari penelitian tersebut menjelaskan bahwa melalui kajian tentang masalah pembelajaran kepemimpinan dan pembentukan model kepemimpinan Hasta Brata, dapat disimpulkan pembentukan kearifan lokal budaya tentang Kepemimpinan Hasta Brata dikembangkan oleh pemikir atau filsuf dan sekaligus pemimpin sehingga diharapkan mampu melengkapi pada kekurangan dari filsafat modern tentang kepemimpinan. Selain itu kearifan tentang kepemimpinan Hasta Brata memungkinkan untuk melakukan observasi dan penyatuan pemahaman secara menyeluruh sementara ilmu pengetahuan modern yang mempunyai keunggulan pada kualitas analisis. Penggabungan dari kedua pemahaman tersebut menghasilkan konsep baru yang lebih akurat untuk melakukan penelitian pada kepemimpinan serta mengetahui sifat dan penerapan kepemimpinan yang adaptif dalam perubahan yang dinamis dari perkembangan jaman yang bersifat global. Dengan melakukan kombinasi konsep Hasta Brata dan teori kepemimpinan modern, akan muncul konsep baru model kepemimpinan teori yang mungkin akan masih terus berkembang untuk meningkatkan outcome organisasi secara efektif.

Selanjutnya Nanjundeswaraswamy (2014) melakukan penelitian dengan tema yang hampir sama yaitu gaya kepemimpinan. Gaya kepemimpinan menunjukkan bahwa dalam suatu organisasi membutuhkan pemimpin yang dapat memahami masalah lingkungan secara global dan kompleks yang berubah dengan cepat. Indeks kepemimpinan yang tinggi tidak berhubungan dengan catatan kinerja, akan tetapi anggota yang baik akan berdampak pada peningkatan kinerja dan peningkatan reputasi organisasi.

Penelitian Kazimoto (2013) yang berjudul "Analysis of Conflict Management and Leadership For Organizational Change”, menunjukkan tidak selalu konflik dalam organisasi itu membawa dampak yang buruk. Akan tetapi konflik juga mampu meningkatkan kualitas kinerja karyawan secara efektif. Konflik dapat mengakibatkan adanya gabungan keterampilan seseorang. Dan faktanya konflik selalu ada pada semua organisasi, baik dalam diri seseorang, organisasi, maupun dalam ketertiban umum. Konflik akan meningkatkan produktivitas, kekuatan dan mempengaruhi usia organisasi tersebut.

Nikoloski (2015) melakukan penelitian "Charismatic Leadership and Power:Using the Power of Charisma for Better Leadership in the Enterprisis” menjelaskan bahwa pemimpin karismatik memiliki karisma, pengetahuan, keterampilan dan kemampuan untuk memimpin karyawan dalam mencapai misi, visi dan tujuan dari perusahaan. Dalam sudut pandang ini, pemimpin karismatik memiliki pengaruh yang besar di dalam sebuah organisasi, menginspirasi, memotivasi dan menanamkan kepercayaan di antara pengikutnya.

Anggraini (2014) meneliti kepemimpinan Presiden Barrack Obama yang mengeluarkan kebijakan Reformasi Pelayanan Kesehatan. Kebijakan tersebut didorong oleh persepsi Obama terhadap biaya pelayanan kesehatan mahal dan tidak terjangkau yang menyebabkan kesenjangan pelayanan kesehatan terhadap masyarakat miskin di Amerika Serikat. Selain itu, Obama juga mempunyai janji kampanye pemilihan presiden pada masa pencalonan sebagai kandidat presiden di Amerika Serikat 2007. Dalam proses perjuangan Rancangan Undang=Undang pelayanan kesehatan, Obama memperjuangkan dengan cara melobi pihak-pihak kubu Partai Demokrat yang merupakan mayoritas anggota Kongres. Pada 23 Maret 2010 Undang-Undang Pelayanan Kesehatan Obama berhasil disahkan dan ditandatangani oleh Presiden Obama. 
Rumusan masalah dalam penelitian ini adalah (1) Apa makna Kepemimpinan Bertumbuh? (2) Apa karakter yang ada dalam kepemimpinan bertumbuh? ( (5) Apa teori yang digunakan dalam Kepemimpinan Bertumbuh? Tujuan penelitian ini adalah (1) Untuk mengetahui makna Kepemimpinan Bertumbuh, (2) Untuk mengetahui karakter yang ada dalam kepemimpinan bertumbuh, (3) Untuk mengetahui teori yang digunakan dalam Kepemimpinan Bertumbuh.

\section{METODE PENELITIAN}

Jenis penelitian yang di gunakan dalam penelitian ini adalah penelitian kualitatif. Menurut Sugiyono (2012) penelitian kualitatif adalah penelitian yang lebih menekankan pada informasi dan data yang terkumpul berbentuk dalam kata-kata atau gambar, sehingga tidak menekankan pada angka. Penelitian kualitatif merupakan proses kegiatan yang mengungkapkan secara logis, sistematis, dan empiris terhadap fenomena-fenomena sosial yang terjadi di sekitar kita untuk di rekonstruksi guna mengungkapkan kebenaran yang bermanfaat bagi kehidupan masyarakat dan ilmu pengetahuan.

Bentuk-bentuk studi kasus yang digunakan adalah studi kasus intrinsik (intrinsic case study). Menurut Stake (1995) studi kasus intrinsik dilakukan untuk memahami secara lebih baik dan mendalam tentang suatu kasus tertentu. Studi kasus dilakukan karena alasan peneliti ingin mengetahui secara intrinsik suatu fenomena, keteraturan, dan kekhususan kasus. Bukan untuk alasan eksternal lainnya. Alasan menggunakan bentuk ini adalah untuk mengetahui secara mendalam mengenai Kepemimpinan Bertumbuh.

Lokasi penelitian ini dilakukan di Universitas Negeri Semarang, Kampus \. Adapun waktu penelitian dimulai pada bulan Februari 2018 sampai dengan September 2018 atau kurang lebih selama 6 bulan. Teknik penentuan informan yang digunakan dalam penelitian ini adalah menggunakan purposive sampling (subjek sesuai tujuan). Iskandar (2009), penentuan subjek berdasarkan tujuan di lakukan untuk meningkatkan kegunaan informasi yang di dapatkan dari subjek yang kecil. Peneliti memilih subjek yang mempunyai pengetahuan dan informasi tentang fenomena yang sedang di teliti, sehingga dapat mengungkapkan banyak informasi dan informan tersebut bisa sedikit banyak, bisa homogen sifatnya dan karakteristiknya juga bisa berubah. Sumber data yang dipergunakan sebagai informan dalam penelitian adalah

Teknik pengumpulan data pada penelitian ini berupa pengumpulan data yang akan diperoleh wawancara, dokumen, dan observasi. Wawancara merupakan pertemuan dua orang untuk bertukar informasi dan ide dengan melalui tanya jawab, sehingga dapaat dikonstruksikan suatu makna dalam topik tertentu. Wawancara digunakan oleh peneliti karena peneliti ingin melakukan sebuah studi pendahuluan untuk menemukan permasalahan yang harus di teliti, tetapi juga apabila peneliti masih menginginkan data-data yang lebih mendalam lagi dari responden. Dalam hal ini adalah wawancara secara langsung dengan Prof. Fathur Rokhman, M.Hum, Ahmad Syaifuddin SS, M.Pd (bidang analisis data akademik UNNES), dan Mulyo Widodo S.Pd, MM (Kabag Kepegawaian UNNES).

Dokumen merupakan catatan peristiwa yang sudah berlalu. Dokumen bisa dalam bentuk tulisan, gambar, atau karya-karya monumental dari seseorang. Dokumen dalam bentuk tulisan bisa berupa dalam catatan harian, sejarah kehidupan (life histories), cerita, biografi, peraturan, atau kebijakan. Dokumen dalam bentuk gambar bisa berupa foto, gambar hidup, atau sketsa. Dokumen dalam bentuk karya bisa berupa karya seni yang dapat berupa gambar, patung, atau film.

Obervasi yang dilakukan adalah mengikuti secara langsung pelatihan Kepemimpinan Bertumbuh yang akan diselenggarakan di UNNES. Pengamatan juga dilakukan dengan oleh peneliti kepada perilaku pemimpin (Prof. Fathur Rokhman, M.Hum) dalam menerapkan Kepemimpinan Bertumbuh. 


\section{Hasil Penelitian}

\section{HASIL PENELITIAN DAN PEMBAHASAN}

Definisi kepemimpinan bertumbuh mengacu pada filosofi pohon. Perhatikanlah bagan berikut:

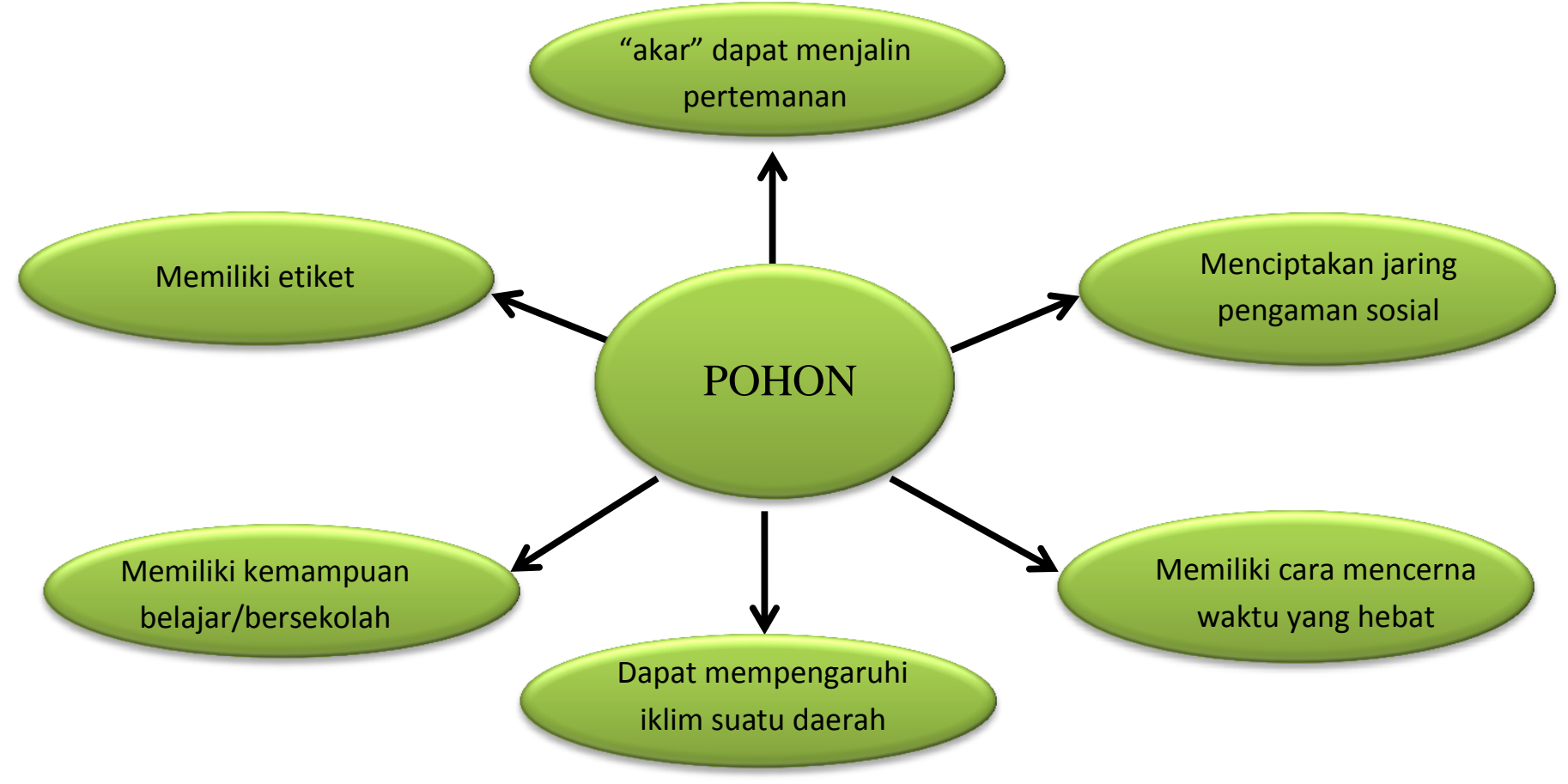

\section{Gambar 1. Kepemimpinan bertumbuh}

Pohon itu (1) Menumbuhkan bibit kepemimpinan, (2) Memperkuat pohon kepemimpinan, (3) Merangkai jejaring pohon kepemimpinan, (4) Pohon kuat menghadapi badai, (5) Menyemai tunas kepempimpinan baru, dan (6) Karakternya adalah karakter yang baik seperti pohon yang tumbuh menjulang tinggi.

Pohon sebagai simbol kepemimpinan bertumbuh, karena (1) Pohon dapat membuat jaringan pertemanan melalui akar-akar yang saling terkait, (2) Pohon dapat menciptakan jaring pengaman sosial bagi sesama pohon, (3) Pohon memiliki etiket, (4) Pohon memiliki kemampuan belajar atau bersekolah, (5) Secara kolektif, pohon dapat mempengaruhi iklim suatu daerah, (6) Dari pertumbuhan dan perilakunya, pohon memiliki cara mencerna waktu yang hebat.

Teori yang digunakan dalam kepemimpinan bertumbuh adalah teori perilaku. Seorang pemimpin dapat menerapkan macam-macam gaya kepemimpinan yang tergantung dari evaluasi pemimpin yang bersangkutan tentang situasi yang dihadapi, kemampuan-kemampuan, keinginan untuk memutuskan, jumlah pengawasan yang akan dijalankan olehnya.

Dasar pemikiran teori perilaku dalam kepemimpinan adalah perilaku pemimpin ketika melakukan kegiatan mempengaruhi suatu kelompok atau anggotanya kearah pencapaian tujuan. Jadi dalam teori ini hal yang dipelajari dan diamati dari seorang pemimpin adalah bagaimana perilaku pemimpin dalam menjalankan tugas sebagai pemimpin, termasuk mengarahkan anggota kelompok agar dapat melakukan pekerjaannya dengan baik demi pencapaian tujuan. Pada initinya, teori ini lebih menekankan pada apa yang dilakukan pemimpin dan bagaimana seorang pemimpin menjalankannya fungsinya. Jadi, dapat dikatakan bahwa perilaku kepemimpinan adalah pola perilaku yang diperlihatkan orang itu pada saat mempengaruhi aktivitas orang lain seperti yang dipresepsikan orang lain.

Point teori perilaku kepemimpinan adalah sebagai berikut (1) Beberapa perilaku tertentu membedakan pemimpin dari mereka yang bukan pemimpin, (2) Merupakan cara seorang pemimpin berperilaku, (3) Menekankan perilaku pimpinan terhadap karyawan.

Kepemimpinan bertumbuh berdasarkan pengalam yang dialami oleh Prof. Dr. Fathur Rokhman, M.Hum saat menduduki kepala lembaga penelitian, Pembantu Rektor bidang Kerja Sama (WR IV) UNNES tahun 2011- 
2008 dan 2015-2011. Pengalaman inilah yang mendajadikan konsep kepemimpinan. Karena, Prof. Dr. Fathur Rokhman, M.Hum meyakini bahwa setiap manusia adalah pemimpin. Ada benih kepemimpinan dalam setiap manusia. Benih ini akan berkecambah, tumbuh menjadi pohon, jika dipelihara dengan tepat. Kelak, pohon itu menjadi rindang yang menyejukkan, menghasilkan bunga yang wangi, dan kelak akan menghasilkan buah dan benih baru sebagai awal regenerasi.

Kepemimpinan bertumbuh termasuk dalam teori kepemimpinan perilaku. Perhatikanlah bagan berikut ini:

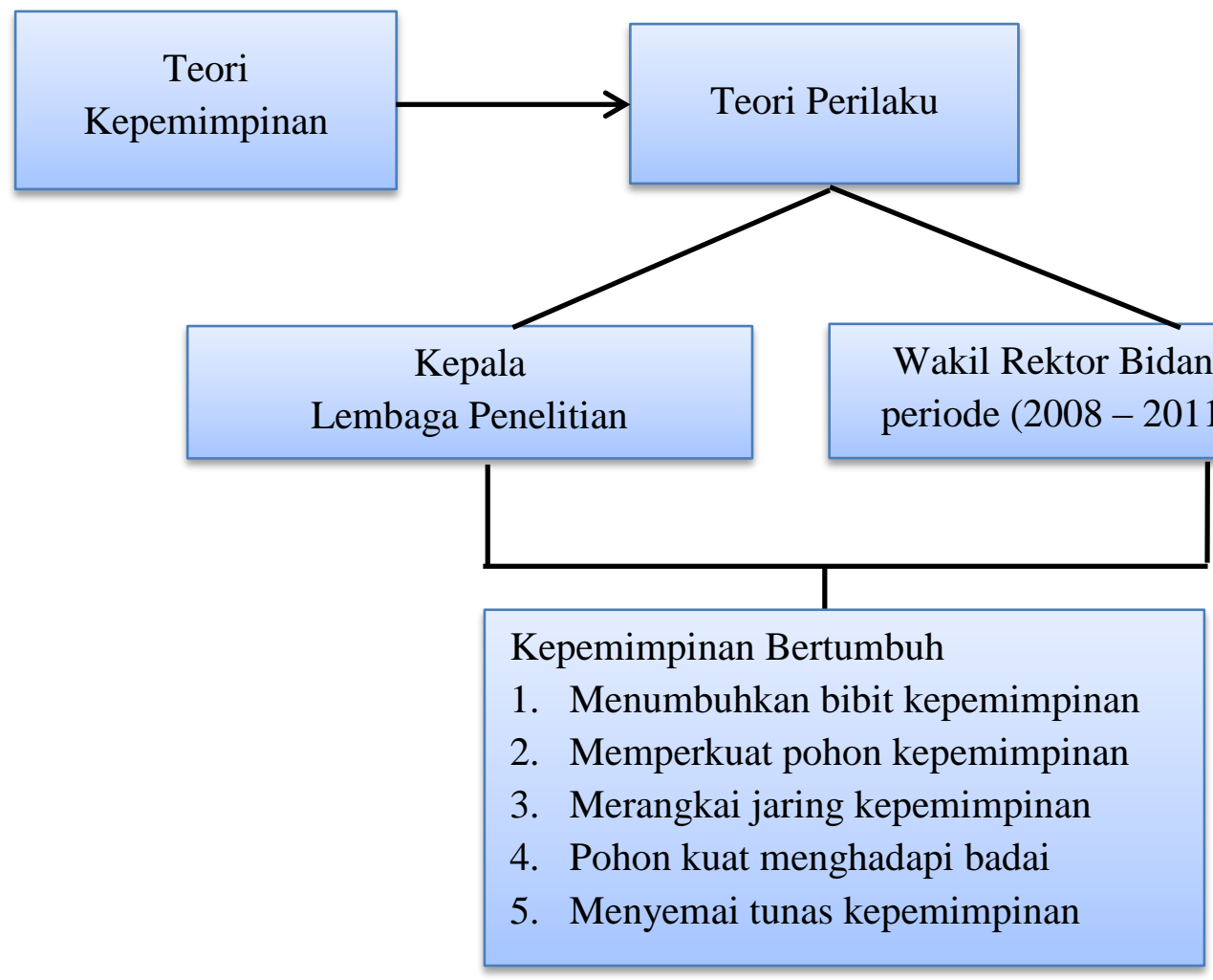

Gambar 2. Teori Kepemimpinan Bertumbuh

Dari bagan di atas terlihat bahwa, perilaku pemimpin muncul berdasarkan pengalaman saat menjadi pemimpin di Lembaga Penelitian dan Wakil Rektor Bidang Kerjasama dua periode (2008 - 2011 dan 2011 - 2015. Dari itu, muncullah konsep kepemimpinan bertumbuh yang memiliki arti (10) Menumbuhkan bibit kepemimpinan, (2) Memperkuat pohon kepemimpinan, (3) Merangkai jaring kepemimpinan, (4) Pohon kuat menghadapi badai, dan (5) Menyemai tunas kepemimpinan.

Ada beberapa karakter dalam kepemimpinan bertumbuh yang dirangkum dalam lima yaitu menumbuhkan benih kepemimpinan, memperkuat kepemimpinan, meningkatkan efektivitas komunikasi, seni menghadapi situasi sulit, dan menyiapkan kepemimpinan berikutnya.

Ada beberapa tips dalam meningkatkan efektivitas komunikasi yaitu pemimpin yang baik adalah komunikator ulung, pemimpin besar belajar mendengar, memperbesar pengaruh dengan komunikasi, menjadi pemimpin di era terbuka, inti komunikasi adalah menumbuhkan rasa memiliki, memelihara kesantunan menghindari kegaduhan, memperkuat kepemimpinan dalam hubungan baik, menjadi pemimpi yang bersahabat, persahabatan erat organisasi sehat, mengelola perbedaan mengelola perdebatan, berhenti berdebat mulai berbegosiasi.

Ketika seseorang atau organisasi mengalami kegagalan, memang rentan muncul perasaan dan sikap negatif. Kepercayaan diri bisa hilang, semangat berkurang, bahkan kepercayaan dalam organisasi dapat memudar. Perasaan ini muncul spontan sebagai respon psikologis seseorang atas situasi yang dikehendakinya. Sekalipun seseorang tahu bahwa perasaaan negatif itu tidak menguntungkan, seseorang itu tidak selalu bisa menghalaunya. 
Para pemimpin, bahkan yang saat ini duduk di puncak, juga pernah mengalami masa-masa sulit seperti itu. sebagai pemimpin, beban yang ditanggungnya akan terasa lebih berat karena ia bertanggung jawab terhadap nasib anggota timnya. Perasaan kecewa, merasa bersalah, atau bakan putus asa sudah demikian dekat dengan dirinya. Namun para pemimpin yang baik lazimnya memiliki ketangguhan, sebuah kemampuan untuk bertahan dari masa sulit. Ketangguhan semacam ini bisa diperoleh seorang pemimpin berkat pengalaman yang panjang. Ketangguhan juga dapat dimiliki seorang pemimpin berkat sikap hidupnya yang positif. Itulah dua faktor yang penting untuk dimiliki pemmpin.

Pengalaman panjang lazimnya mengajarkan seseorang untuk tidak kaget menghadapi situasi baru. Meskipun situasi itu sama sekali tidak pernah diramalkannya, ia berusaha menyesuaikan diri dengan menjajaki berbagai kemungkinan. Pribadi dengan ketangguhan menghadapi kesulitan akan bersikap realistis bahwa situasi yang dihadapinya sulit. Namun dengan pengalamannya, situasi sulit tersebut dapat diuraikan dengan sejumlah tindakan.

Beberapa prestasi yang diraih oleh UNNES dalam menggunakan kepemimpinan bertumbuh adalah pada tanggal 29 Desember 2016 Badan Akreditasi Nasional Perguruan Tinggi (BAN-PT) menginformasikan beberapa perguruan tinggi yang meraih status akreditasi A (2016), publikasi di jurnal terakreditasi minimal 300 (2015), Universitas Negeri Semarang (Unnes) menerima penghargaan dari Lembaga Prestasi Indonesia-Dunia (LEPRID) atas tes anti narkoba bagi mahasiswa (2015). Mahasiswa meraih emas pada kompetisi Olimpiade Matematika dan Ilmu Pengetahuan Alam (ON MIPA) Perguruan Tinggi di Jakarta (2016).

Prestasi UNNES di 2017 publikasi di jurnal internasional bereputas, jurnal terindeks Scopus (1 jurnal), jurnal terakreditasi nasional (11 jurnal), jurnal terindeks DOAJ (83 jurnal) terbanyak di Indonesia, jurnal terindeks google Scholar (119 jurnal), dan artikel terindeks Scopus (346 artikel). Selain itu, UNNES pada UI Green Metric peringkat 4 Indonesia dan peringkat 84 dunia. Sedangkan pemeringkatan Kemenristekdikti UNNES nomor 16 Nasional.

Prestasi bidang akademik, program studi terakreditasi Unggul (A) sebanyak 46 (46,93\%), prodi terakreditasi B 33 prodi (33,37\%), publikasi ilmiah internasional 346 karya ilmiah, dan PTN favorit nomor 7 pada SNMPTN dan SBMPTN.

Prestasi bidang umum dan keuangan tata kelola keuangan memperoleh WTP 7 tahun berturut-turut, penerapan sistem remunersi menjadi rujukan, peringkat 7 realisasi anggaran PTN BLU, peringkat 7 realisasi fisik PTN BLU, dan peringkat 8 deviasi terbesar antara serapan anggaran dan realisasi fisik PTN BLU.

Prestasi bidang kemahasiswaan diantaranya PIMNAS nomor 7 nasional, pendidikan bela negara, pemenang pengelola bidikmisi terbaik 1, pemenang kategori pelaksanaan kegiatan kemahasiswaan, dan pemenang kategori prestasi kegiatan internasional. Sedangkan, peringkat kinerja fakultas juara umum 1 Fakultas Matematika dan Ilmu Pengetahuan Alam (FMIPA), juara umum 2 FIK, dan juara umum 3 FT.

UNNES pada tahun 2018 nanti menetapkan sebagai tahun internasionalisasi yakni menekankan pada pemingkatan mutu tridharma sesuai standar internasional, layanan prima, reformasi birokrasi, dan zona integritas. Dengan konsep penyelenggaraan tridharma PT yang digunakan bisa bersanding dan bersaing dengan perguruan tinggi di dunia (https://unnes.ac.id/berita/2017-unnes-penuh-prestasi-program-internasionalisasi-unnes-2018mantap/.

\section{Kesimpulan}

\section{PENUTUP}

Simpulan dalam penelitian ini adalah (1) Makna Kepemimpinan Bertumbuh mengacu pada filosofi pohon. Dimana, pohon itu (a) Menumbuhkan bibit kepemimpinan, (b) Memperkuat pohon kepemimpinan, (c) Merangkai jejaring pohon kepemimpinan, (d) Pohon kuat menghadapi badai, dan (e) Menyemai tunas kepempimpinan baru. (2) Karakter dalam kepemimpinan bertumbuh yaitu menumbuhkan bibit kepemimpinan, yang meliputi memahami kemanusiaan dan kepemimpinan sebagai jalan spiritual, dengan cara (a) Memahami kemanusiaan, (b) Menemukan kepemimpinan, dan (c) Memahami serta mengutamakan martabat kemanusiaan adalah bibit unggul kepemimpinan. (3) Teori yang digunakan dalam kepemimpinan bertumbuh adalah teori perilaku. Seorang pemimpin dapat menerapkan macam-macam gaya kepemimpinan yang tergantung dari evaluasi pemimpin yang bersangkutan tentang situasi yang dihadapi, kemampuan-kemampuan, keinginan untuk memutuskan, jumlah pengawasan yang akan dijalankan olehnya. 


\section{Saran}

Saran dalam penelitian ini adalah (1) Perlunya dukungan teori yang lebih kuat dalam memaknai kepemimpinan bertumbuh, karena pengambilan kata bertumbuh berdasarkan kepada filosofis pohon, sehingga, diperlukan kajian teori yang mendalam dari segi konsep kepemimpinan, (2) Lembaga atau organisasi sangat cocok/tepat menggunakan teori ini di saat sekarang, karena sesuai dengan kondisi masyarakat. Terlebih, kepemimpinan bertumbuh berdasarkan kepada pengalaman seorang pemimpin.

\section{DAFTAR PUSTAKA}

Anggraini, Sylvia Dwi. 2014. Obamacare (Reformasi Pelayanan Kesehatan Amerika Serikat 2010). Skripsi. Universitas Jember.

Harakatuna. 2017. Kepemimpinan Bertumbuh ala Prof. Fathur Rokhman.

https://harakatuna.com/kepemimpinan-bertumbuh-ala-prof-fathur-rokhman.html.

Hudaya, Z.A. \& Nugroho, S.W.D. 2013. Kearifan lokal budaya Jawa sebagai basis model kepemimpinan yang efektif. Sustainable Competitive Advantage (SCA), 3(1). Tersedia di http://jp.feb.unsoed.ac.id/index.php/sca-1/article/view/222.

Hughes, R. L., Ginnet, R. C., and Curphy, G. J.2012.Leadership:Memperkaya Pelajaran dari Pengalaman.Edisi Ketujuh.Jakarta:Salemba Humanika.

Iskandar. 2009. Metodelogi Penelitian Pendidikan dan Sosial (Kuantitatif dan Kualitatif). Jakarta: GP Press.

Kazimoto, P. 2013. Analysis of Conflict Management and Leadership for Organizational Change. International Journal of Research In Social Sciences, 3(1): 16-25.

Mukti, Akbar Hari. 2016. Rektor Unnes akan Lucurkan Buku Kepemimpinan Bertumbuh. Tribun Jateng Edisi $9 / 12 / 2016$.

Nanjundeswaraswamy, T. S and Swamy, D. R. 2014 "Leadership Styles”. Published by Depart ment of Indust rial Engineering and Management, JSS Academy of Technical Educat ion, Bangalore, INDIA. Vol. 7, No. 2, $57-62$.

Nikoloski, Krume. 2015. Charismatic Leadership and Power: Using the Power of Charisma for Better Leadership in the Enterprisis. Journal of Process Management- New Technologies International, 3(2):18-27.

Rokhman, Fatkhur. 2016. Kepemimpinan Bertumbuh. Semarang: Cakrawala Media.

Sugiyono. 2012. Metodelogi Penelitian. Bandung:Alfabeta.

Stake, E. Robert. 1995. The Art of Case Study Reseach. Sage Publication.

Yuwono, Setyo. 2017. One Day Training Inovasi UNNES Perkuat Kepemimpinan Bertumbuh. http://unnes.ac.id/berita/one-day-training-inovasi-unnes-perkuat-kepemimpinan-bertumbuh/. 
http://jp.feb.unsoed.ac.id/index.php/sca-1/article/view/222. didonwload pada tanggal 1 Oktober 2018

(https://unnes.ac.id/berita/2017-unnes-penuh-prestasi-program-internasionalisasi-unnes-2018-mantap/. didonwload pada tanggal 1 Oktober 2018 